\title{
Twenty Years of Physical Mapping of Major Ribosomal RNA Genes across the Teleosts: A Review of Research
}

\author{
E. Gornung \\ 'Charles Darwin' Department of Biology and Biotechnologies, University of Rome 'La Sapienza', Rome, Italy
}

\section{Key Words}

Actinopterygii $\cdot$ FISH $\cdot$ NOR $\cdot 45 \mathrm{~S}$ rRNA genes $\cdot$ Teleostei

\begin{abstract}
Molecular cytogenetic data on the number and position of $45 \mathrm{~S}$ ribosomal RNA genes ( $\mathrm{rDNA}$; located in nucleolus organizing regions, NORs) detected by FISH in 330 species of 77 families and 22 orders of bony fishes (Teleostei) and, additionally, 11 species of basal ray-finned fishes are compiled and analyzed. The portion of species with single rDNA sites in the sample amounts to $72 \%$. The percentage of species with multiple NORs decreases with increasing numbers of rDNA loci per genome, i.e. scarcely $3 \%$ of species carry 4 or more rDNA-bearing chromosome pairs. $43 \%$ of all rDNA sites analyzed occur terminally on the short arms of chromosomes or constitute them. In general, terminal rDNA sites account for $87 \%$ of all examined cases. Interspecific variation in the location of single rDNA sites among related taxa, polymorphisms of multiple NORs in some groups of teleosts and analytical outcomes on the subject are reviewed.
\end{abstract}

(c) 2013 S. Karger AG, Basel
(C) 2013 S. Karger AG, Base

$1424-8581 / 13 / 1413-0090 \$ 38.00 / 0$
In the preface to the latest checklist of fish karyotypes, Ryoichi Arai raises some challenging questions that remain to be answered with regard to evolutionary karyology of fishes. One of them is: 'What is the phylogenetic significance of differences in the number and location of NORs as shown by different banding methods especially by the FISH method...?' [Arai, 2011]. Nucleolus organizer regions (NORs) are the chromosomal regions where the major $(45 \mathrm{~S}=18 \mathrm{~S}+5.8 \mathrm{~S}+28 \mathrm{~S})$ ribosomal $\mathrm{RNA}$ (rRNA) genes (rDNA) are located. The present study is an attempt to assess and analyze wide-ranging data on chromosome mapping of rDNA by fluorescence in situ hybridization (FISH) in fishes, mainly teleosts, and to outline a range of views on the subject. In teleosts, extensive use of FISH for mapping chromosome markers, first of all rDNA, began in the mid-1990s. NORs, detected by silver nitrate or fluorochrome staining, had hitherto been examined in more than 200 fish species [e.g. Klinkhardt et al., 1995] and were believed to be useful cytosystematic characters [Amemiya and Gold, 1988, 1990]. From then on, molecular cytogenetic studies produced further and more detailed information on the number of rDNA sites and their chromosomal locations in various taxa of fishes. Evidently, this knowledge is destined to increase continuously, since Teleostei is the largest group of extant verte-

\section{KARGER}

E-Mail karger@karger.com www.karger.com/cgr
Dr. Ekaterina Gornung

'Charles Darwin' Department of Biology and Biotechnologies University of Rome 'La Sapienza', via Alfonso Borelli 50 IT-00161 Rome (Italy)

E-Mail ekaterina.gornung@gmail.com 
brates ( 26,840 species) [Ravi and Venkatesh, 2008; Peng et al., 2009] organized into 40 orders [Nelson, 2006]. However, NORs have been studied by strictly molecular cytogenetic approaches only in a small percentage of teleost species (here estimated as $\sim 1.3 \%$ ). Moreover, 18 teleost orders, among them some long-standing problematic taxa in fish systematics, such as Ateleopodiformes, Beryciformes, Lampridiformes, Lophiiformes, Ophidiiformes, Polymixiiformes, Stephanoberyciformes, and Zeiformes [Nelson, 2006], have not been investigated thus far.

In this article, molecular cytogenetic data regarding the number and position of $45 \mathrm{~S}$ rDNA sites of 330 teleost species and subspecies belonging to 77 families of 22 orders and, in addition, 11 species from 4 families of basal ray-finned fishes (Polypteriformes, Acipenseriformes, and Lepisosteiformes) were compiled from the literature and examined (for a complete list of surveyed species, the data and corresponding references, see online suppl. tables 1, 2 and references; for all online suppl. material, see www.karger.com/doi/10.1159/000354832). The goal of such a wide-ranging analysis is to try to understand whether the rDNA sites are randomly distributed or occupy particular loci on chromosomes, and whether the karyotype structure has an effect on the evolutionary repatterning of rDNA sites in fishes. However, this report is a 'snapshot' of ongoing research and therefore destined to be reassessed shortly.

\section{Background}

\section{Organization and Evolution of $r R N A$ Genes}

In eukaryotes, the genes for a single rRNA of the small ribosomal subunit (18S RNA) and 2 RNAs of the large subunit (28S and 5.8S) together with 2 internal (ITS1 and ITS2) and 1 external transcribed spacers are grouped in 1 transcription unit coding for a $45 \mathrm{~S}$ primary transcript. The transcribed units are separated by non-transcribed intergenic spacers. The $45 \mathrm{~S}$ rRNA genes are organized in chromosomes in tandem arrays of hundreds to thousands of units. The important characteristic of rDNA repeated units is their sequence uniformity due to concerted evolution of the arrays, which is, in any organism, a natural consequence of the unequal crossover process, which was demonstrated mathematically, by computer simulation and in direct experiments in yeast [reviewed in Elder and Turner, 1995; Liao, 1999]. The homogeneity of rDNA, therefore, largely depends on the rates of sister chromatid and interchromosomal (homologous

Chromosomal Mapping of rDNA in

Teleosts and nonhomologous) exchanges. Another homogenizing mechanism is the gene conversion [Nagylaki, 1984]. Finally, the long-standing 'birth-and-death' evolutionary process, based on gene duplication with subsequent deletion of some duplicated copies, may also account for rDNA homogeneity, as it was shown for most non-rRNA multigene families [reviewed in Nei and Rooney, 2005]. Notwithstanding the homogenizing mechanism involved, the dynamic nature of the rDNA loci leads to their continuous repatterning, though proceeding at different rates in different lineages. The rDNA coding sequences are known to be the most conserved genes among eukaryotes, albeit some inter- and intraspecific variation occurs. Thus, maintenance of discrete rDNAlength variants in Salvelinus namaycush indicates that the rate of gene conversion may be insufficient to produce strictly homogeneous copies across the genome [Reed et al., 2000]. Also, the ITS1 sequences may show a degree of variability suitable for species identification and phylogenetic analysis, as reported for Salvelinus mal$m a$ [Phillips et al., 1999]. The intergenic spacers, not subjected to selective pressure as the transcribed units, differ significantly even between closely related species [reviewed in Eickbush and Eickbush, 2007].

\section{Cytogenetic Methods for Detecting rDNA Sites}

NORs are the most widely documented chromosome regions in fishes and are most extensively investigated by FISH, too. Moreover, FISH allows to detect all or the maximum possible number of NORs present in a chromosome complement, in contrast with the cytochemical approaches - staining with silver nitrate [Goodpasture and Bloom, 1975; Howell and Black, 1980] and fluorochromes, such as chromomycin $\mathrm{A}_{3}\left(\mathrm{CMA}_{3}\right)$ [Amemiya and Gold, 1986; Mayr et al., 1986]. The silver binds to NOR proteins: the RNA polymerase I subunit, the $50-\mathrm{kDa}$ UBF (upstream binding factor), the $135-\mathrm{kDa}$ NOR protein, and SL1 (promoter selectivity factor) associated with active rRNA genes of nucleoli [Roussel and Hernandez-Verdun, 1994; Whitehead et al., 1997]. Application of silver staining has 2 deficiencies: (1) the method reveals nucleolar argyrophilic proteins retained in metaphase chromosomes and, therefore, only the NORs active in the previous interphase (AgNORs) are detected; (2) sometimes, silver binds to chromosome regions not properly corresponding to NORs, as centromeres or particular heterochromatin blocks. The formation of such pseudo-AgNORs, positive in silver staining, has been observed in some fishes [Ozouf-Costaz et al., 1997; Pisano et al., 2000; Caputo et al., 2002; Gromicho et al., 2005] and other ani- 
mals [Dobigny et al., 2002; Cabrero and Camacho, 2008] and may be due to the sequences that bind the RNA polymerase I transcription factor UBF, integrated at ectopic chromosome sites [Wright et al., 2006].

The GC-specific fluorochrome $\mathrm{CMA}_{3}$ stains NORs regardless of their activity, probably because of local changes in base composition (increase in GC) due to a process of so-called GC-biased gene conversion that involves rDNA in many vertebrates, including ray-finned fishes, especially Clupeiformes, Cypriniformes, and Siluriformes [Escobar et al., 2011]. $\mathrm{CMA}_{3}$ staining has also certain limitations because particular GC-rich chromosome regions other than rDNA sites, occasionally present in fish karyotypes, may exhibit bright fluorescence. Thus, in the archaic Polypterus ornatipinnis (Polypteriformes), $\mathrm{CMA}_{3}$ marked both NORs and additional sites lacking rDNA, as well as all centromeres [Morescalchi et al., 2011]. In zebrafish, more than a half of the chromosomes show $\mathrm{CMA}_{3}$-positive bands due to GC-rich repetitive DNA families [Gornung et al., 1997; Phillips and Reed, 2000]. Moreover, in the cyprinid Squalius alburnoides, not only some other regions besides NORs were stained with $\mathrm{CMA}_{3}$ and $\mathrm{Ag}$, but also the majority of the rDNA sites were not detected [Gromicho et al., 2005]. Finally, $\mathrm{CMA}_{3}$ either does not stain NORs in sturgeons [Sola et al., 1994] or marks chromosomes irrespective of rDNA [Fontana et al., 1998]. This unconventionality correlates with an overall decline in the GC-content per haploid genome in Acipenseriformes associated with an increase in C-value due to polyploidization [Bernardi and Bernardi, 1990]. Still, $\mathrm{CMA}_{3}$ marks all $\mathrm{rDNA}$ sites in the distantly related tetraploid paddlefish, Polyodon spathula [Symonová et al., 2010].

To maintain data consistency, in the present article only $45 \mathrm{~S}$ rDNA sites localized through FISH are included.

\section{The Number of rDNA Sites per Karyotype}

Concerning the number of rDNA sites, conceived as the number of rDNA-bearing chromosome pairs per karyotype, the teleost species presently examined show expressive bias for single NORs. In fact, the number of species with single rDNA sites in a sample of 330 teleost species amounts to 237 (72\%) (fig. 1). Among the basal teleosts, Arapaima gigas (Osteoglossidae, Osteoglossomorpha) [Marques et al., 2006; da Rosa et al., 2009] and 8 representative species of 4 families of Anguilliformes (Elopomorpha) [Martínez et al., 1996; Coluccia et al., 2001, 2010; Deiana et al., 2006] all have single rDNA sites.

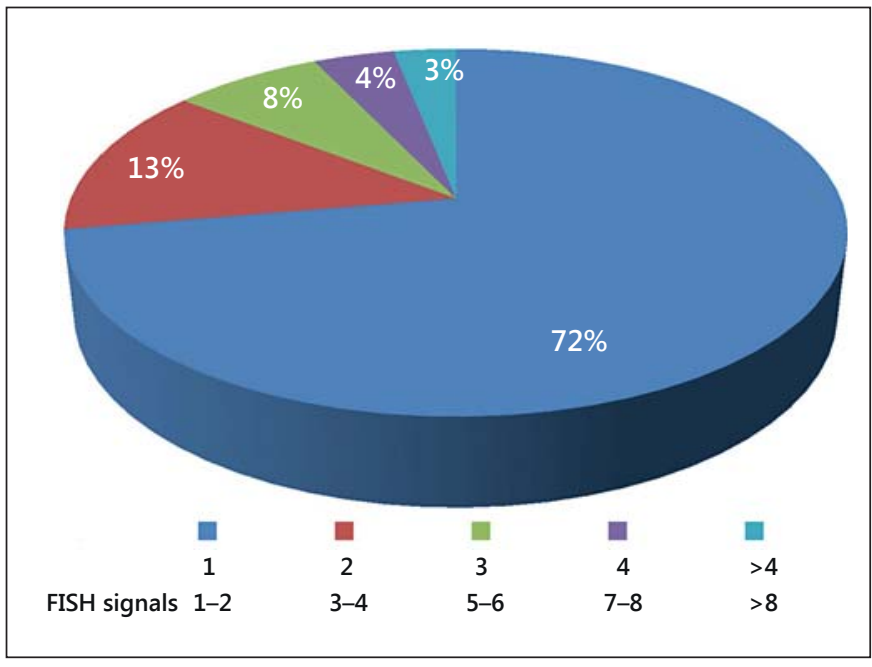

Fig. 1. The relative amount of fish karyotypes with 1,2, 3, 4, and $>4$ rDNA-bearing chromosome pairs.

The species of the ostariophysians that show exclusively single-site patterns belong to the following 13 families of the 20 families so far studied: Anastomidae, Gasteropelicidae and Parodontidae (Characiformes); Gymnotidae, Sternopygidae and Hypopomidae (Gymnotiformes); Callichthyidae, Heptapteridae, Loricariidae (except Hypostominae), Pimelodidae, Pseudopimelodidae, Siluridae, and Trichomycteridae (Siluriformes). In contrast, species belonging to Erythrinidae, Cobitidae, as well as species of the characid subfamilies Bryconinae and Serrasalminae (Characiformes) and some cyprinid species (Cypriniformes) reveal remarkable variation in the number of rDNA clusters. In protacanthopterygians, multiple NORs appear in salmons, as in Salmo trutta [Caputo et al., 2009] and Salvelinus fontinalis [Fujiwara et al., 1998], the species that show the highest number of rDNA sites so far reported, as well as in 2 umbrid species (Esociformes) [Ráb et al., 2002]. On the other hand, multiple rDNA sites are more an exception than a rule within the acanthopterygian species studied so far, such as Aphanius fasciatus (Cyprinodontiformes) [Vitturi et al., 2005], Nerophis ophidion and Syngnathus abaster (Syngnathiformes) [Libertini et al., 2006], Monopterus albus and Synbranchus madeira (Synbranchiformes) [Ji et al., 2003; Carvalho et al., 2012]. In Perciformes, a highly conserved single-site pattern is noticeably altered only within the suborder Labroidei, especially in cichlid subfamilies Cichlasomatinae and Pseudocrenilabrinae [Gross et al., 2010; Poletto et al., 2010b], and sporadically in other taxa, 


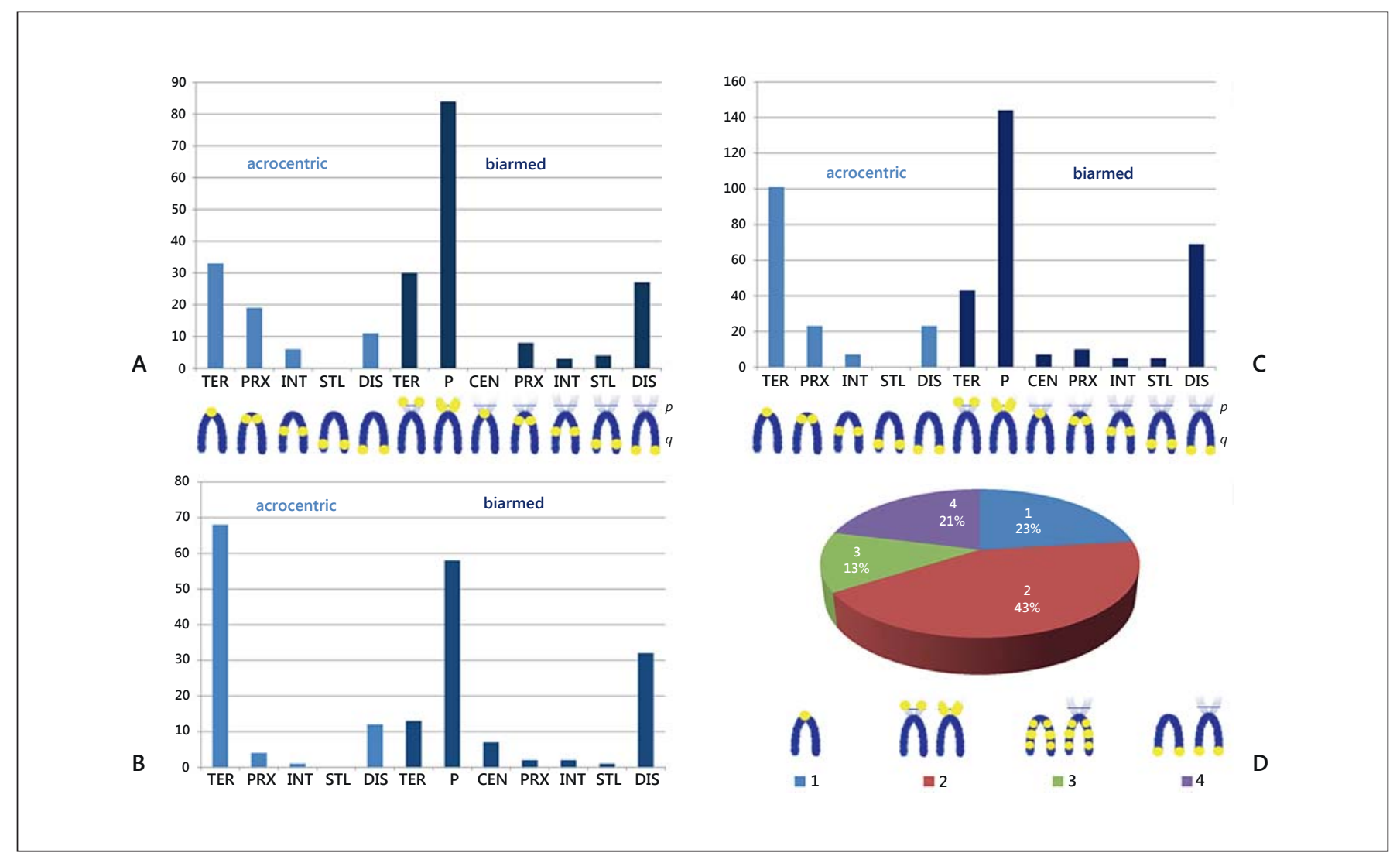

Fig. 2. Number of rDNA sites at different locations along chromosomes in fish karyotypes. A Distribution of single rDNA sites (230) and B multiple rDNA sites (200). C Entire data set (430 patterns). D Relative proportions of the rDNA locations. 1 = Centromericterminal in acrocentric chromosomes; 2 = terminal on p-arm or entire $\mathrm{p}$-arm; 3 = any internal location in any type of chromosome;
4 = distal position in any type of chromosome. CEN = Pericentromeric; DIS = terminal on the q-arms of acrocentric or biarmed chromosomes; INT = interstitial; $\mathrm{P}=$ within the $\mathrm{p}$-arm or entire p-arm; PRX = proximal; STL = subtelocentric; TER = centromeric termini of acrocentric chromosomes (terminal-centromeric sensu Takai and Ojima [1986]) or terminal on the p-arms. as in 1 species of Labridae, Coris julis [Mandrioli et al., 2000a], in 1 species of Sparidae, Diplodis sargus [Merlo et al., 2013], and in 2 notothenioid species [Caputo et al., 2002; Ghigliotti et al., 2007]. Likewise, among several species of Tetraodontiformes with single rDNA sites, multiple rDNA sites have been detected in only 1 pufferfish, Canthigaster figueiredoi [Martinez et al., 2010].

A single NOR-bearing chromosome pair has been originally assumed to be the plesiomorphic condition in fishes [Amemiya and Gold, 1988]. The evidence in the most primitive actinopterygians confirms this assumption: among the basal actinopterygians, both $P$. ornatipinnis [Morescalchi et al., 2011] and Lepisosteus osseus [Ráb et al., 1999], have 1 pair of rDNA-bearing chromosomes. The archaic Acipenseriformes, a singular lineage of ancient ray-finned fishes that have undergone manifold polyploidization with subsequent remodeling of karyotypes [Birstein et al., 1997], represent an exception, but the number of rDNA sites per karyotype, though, reflects a ' 1 NOR/haploid genome' condition. The 8 species of sturgeons present multiple rDNA sites, i.e. $3-4$ or 5-6 NOR-bearing chromosome pairs in the species with $\sim 120$ and 250-270 chromosomes, respectively, which is consistent with the degree of polyploidization [Tagliavini et al., 1999; Fontana et al., 2003, 2004]. Accordingly, 1 of the 2 extant paddlefish species (Polyodontidae), P. spathula $(4 n=120)$, shows rDNA sites on 4 pairs of chromosomes [Symonová et al., 2010].

The portion of teleost species with multiple NORs decreases with increasing numbers of rDNA loci per genome, i.e. scarcely $3 \%$ of species carry 4 or more rDNAbearing chromosome pairs (fig. 1). 


\section{Chromosomal Locations of rDNA Clusters}

The number of rDNA loci at particular positions along the chromosomes estimated in the presently studied sample is illustrated in figure 2. The distribution of rDNA sites along the chromosomes varies between the karyotypes with single (fig. 2A) and multiple (fig. 2B) rDNA sites. In the first group, the prevailing rDNA location is on the short (p) arm of subtelo- or submetacentric chromosomes, followed by various terminal positions. This pattern is expected to correlate with the distribution of major rDNA sites in species with multiple NORs. In the second group, the frequency of rDNA sites at the centromeric termini of acrocentric chromosomes increases markedly if compared to the first group, which indirectly indicates the preferential locations of additional rDNA sites. On the whole, $43 \%$ of all $\mathrm{rDNA}$ sites here analyzed occur terminally on the short arms of chromosomes or constitute them, $23 \%$ occur at centromeric termini of chromosomes described as acrocentric or telocentric, and $21 \%$ occur at distal termini of any morphological type of chromosomes. The remaining $13 \%$ of rDNA sites are found in internal positions on chromosomes (classified as pericentromeric, proximal, interstitial, and subtelocentric) (fig. 2C, D). rDNA sites at any chromosome termini, therefore, amount to $87 \%$ of all examined patterns.

\section{Single rDNA Sites: Interspecific Variation in Chromosomal Location within Groups of Related Taxa}

Several groups of species of the same higher-order taxon comprising a number of representative species enough to carry out a basic comparative evaluation, and which all (or almost all) have karyotypes with a single rDNA-bearing chromosome pair, were examined. In some of these groupings, the related species show highly or reasonably conserved diploid chromosome numbers and either conserved or morphologically diversified karyotypes, whereas others show considerable variation in both diploid number and chromosomal formulae. Thus, in the family Blenniidae, belonging to the first category, a $2 \mathrm{n}=48$ largely acrocentric karyotype, typical of perch-like species, is highly conserved. The rDNA sites occur mainly at centromeric termini of similar large subtelocentric chromosomes, but are also found in presumably derived locations in the 2 species Lipophrys pavo and Parablennius gattorugine. The derived condition is supposed to have originated by fixation of a pericentric inversion and a translocation by unequal crossing-over during paleogeographic isolation of respective ancestral lineages, respectively [Caputo et al., 2001].

In the Mugilidae, another family with low karyotype variation, all species, except one, carry single rDNA sites. The distal rDNA site on the largest chromosome in the species of Mugil and the rDNA sites constituting the short arms of 2 distinct chromosome pairs in Liza-Chelon species and Oedalechilus labeo are supposed to be due to 2 unrelated translocation events [Sola et al., 2007]. Among the few species of Lycodinae (Zoarcidae, Perciformes) studied so far, 1 Antarctic species, Lycodichthys dearborni, and 4 Arctic Lycodes species share the remarkably conserved $2 \mathrm{n}=48$ all-acrocentric karyotype and a single paracentromeric location of rDNA, while only $L$. eudipleurostictus has rDNA sites at centromeric termini of 1 apparently diverse chromosome pair. While no hypothesis on primitive/derived condition has been proposed in this group, a translocation of rDNA sites has been implied [Ghigliotti et al., 2012].

The karyotypes of almost all species of the Cichlinae (Perciformes, Labroidei) maintain $2 \mathrm{n}=48$ chromosomes, but have highly diversified chromosomal formulae. All species, except one, Mesonauta festivus, have single rDNA sites, though at different locations; according to the authors, likely due to numerous macrochromosomal rearrangements of karyotypes in this cichlid subfamily [Poletto et al., 2010b].

The single rDNA site pattern is also generally conserved in the perciform suborder Notothenioidei (with relatively low total numbers of species per family), with the exception of Pagetopis macropterus (Channichthyidae) and Trematomus hansoni (Nototheniidae) [Caputo et al., 2002; Mazzei et al., 2004, 2006; Ghigliotti et al., 2007]. Most of the notothenioid families enclose species that show $2 n=48$ karyotypes with distinct (within each family) chromosomal formulae. The bidirectional changes in diploid chromosome numbers $(2 \mathrm{n}=24,2 \mathrm{n}=32$, $2 \mathrm{n}=58 / 57 \mathrm{XY}$ ) reported in the genus Trematomus did not involve the chromosome pair with NORs. The authors suggest that variation in rDNA location in the whole grouping may be conducted to chromosomal rearrangements in the basal lineages of non-Antarctic notothenioid fishes, which consisted in dislocation of interstitial NORs in the basal lineages (Bovichtidae, Pseudaphritidae) to centromeric termini of acrocentric chromosomes in Eleginopidae.

In the derived Antarctic clade to which Nototheniidae, Bathydraconidae, and Channichthyidae belong, the loca- 
tions of single rDNA sites are widely conserved. In these taxa, rRNA genes are clustered along entire chromosome arms of metacentric chromosomes, vastly enriched in heterochromatin [Pisano and Ghigliotti, 2009].

The species of Anostomidae (Characiformes) studied so far share the chromosome number $(2 \mathrm{n}=54)$, but show noticeable differences in their karyotypes associated with a particular heterochromatin distribution, which, according to the authors, has likely contributed to the dislocation of rDNA sites from their plesiomorphic position [da Silva et al., 2013]. Indeed, the rDNA sites are generally located terminally on the long arms of dissimilar chromosome pairs in Leporinus and Schizodon and are closely associated with the adjacent heterochromatin [Koehler et al., 1997]. Besides, in 2 congeneric species, Leporinus reinhardti and L. striatus, rDNA sites occur in the interstitial region of the short arms of a submetacentric chromosome, most likely as a result of inversion [Cioffi et al., 2012; da Silva et al., 2013].

The species of Neoplecostominae and Hypoptopomatinae (Siluriformes, Loricariidae) are characterized by conserved diploid numbers, while diversification of karyotypes is mainly attributed to pericentric inversions [Kavalco et al., 2005a]. The interspecific analysis once again shows a remarkable role of heterochromatin in repatterning of NORs [Ziemniczak et al., 2012]. In these species, interstitial single rDNA sites are conserved in a putative homeologous pair (a plesiomorphic position in the family) [Artoni and Bertollo, 2001], while the morphology of NOR-bearing chromosomes varies mainly due to accumulation of neighboring heterochromatin. In contrast, in Loricariinae, evolution diversified karyotypes by centric fissions, centric fusions, as well as pericentric inversions in both number and chromosome morphology. In the genus Harttia, rDNA sites are located at either termini of distinct acro-/subtelocentric chromosomes, but interstitial locations have been also revealed in some species by other techniques [Kavalco et al., 2005a; Blanco et al., 2012]. The dislocation of rDNA sites from the plesiomorphic position most likely follows from overall chromosome rearrangements in this genus. Interestingly, in the related Rineloricaria lima, karyotype variation is very high even among populations $(2 \mathrm{n}=66-70, \mathrm{FN}=$ 72-74), but, evidently, the rDNA-bearing chromosome pair is not involved in respective chromosome rearrangements since rDNA sites are found in the short arms of the first chromosome pair in all examined cytotypes [Rosa et al., 2012].

The so far studied species of another family of Siluriformes, Pimelodidae, show karyotypic variability with a predominance of $2 \mathrm{n}=56$ chromosomes. A high degree of rDNA site conservation is illustrated by 8 congeneric species of Pimelodus, which all bear rDNA sites on apparently homeologous chromosomes, while intergeneric diversification of rDNA locations must be due to inversions [Souza et al., 2004; Garcia and Moreira Filho, 2005, 2008].

Finally, 7 species of the 5 genera of Achiridae (Pleuronectiformes) present conspicuous inter- and intrageneric karyotype differences, but all have a single rDNA-bearing chromosome pair, though not even two are homeologous [Carvalho de Azevedo et al., 2005]. The terminal rDNA sites are chiefly located on the short arms of submetacentric chromosomes. In 1 species, Gymnachirus nudus, the rDNA sites occur terminally, but on the long arm of a submetacentric chromosome. According to the authors, important chromosome rearrangements that occurred in this family involved chromosome segments encompassing the rDNA cluster.

Summarizing these data, the single $45 \mathrm{~S}$ rDNA sites show a predominantly fixed position in karyotypes of teleosts. Interspecific variation in chromosome location of single rDNA sites in conserved karyotypes, i.e. karyotypes without multiple visible rearrangements in a genus or a family, is generally reported to be due to pericentric inversions and fixed translocations of terminal NORs. Therefore, exceptions to the common rDNA location in a group of related species might be relevant to taxonomic studies. The dislocation of single rDNA sites from a plesiomorphic position in a group of related species with diversified karyotypes is explained in 2 ways: (1) as a consequence of fixation of chromosomal rearrangements, which occurred in ancestral karyotypes and passively involved rDNA-bearing chromosome segments (translocations, inversions) or entire chromosomes (fission-fusions) and (2) as a variation in position of rDNA related to NOR-associated heterochromatin that remodels homeologous chromosomes and/or promotes interchromosomal rDNA exchanges.

\section{Interspecific and Intergeneric Variation in the Number and Location of Multiple rDNA Sites}

Most of the species with multiple 45S rDNA sites so far reported are ostariophysians. A notable variability of the number and chromosomal distribution of multiple rDNA sites, concurrent with either conserved or diversified karyotypes, is described in some species of the largest family of Characiformes, Characidae [Almeida-Toledo et 
al., 2000], and in the small families Erythrinidae [Cioffi et al., 2009; Cioffi and Bertollo, 2010] and Prochilodontidae [Hatanaka and Galetti, 2004]. However, rDNA clusters occur terminally on a unique large submetacentric pair in the 7 species of the genus Brycon - a condition proposed as primitive in the subfamily [Wasko and Galetti, 2000], whereas additional tiny rDNA sites were detected only in B. amazonicus [Mariguela et al., 2010]. On the other hand, in nearly all of the 8 species and populations of the karyotypically conserved bryconine genus Triportheus, rDNA sites show remarkable inter- [Diniz et al., 2009] and intraspecific variation, as in T. venezuelensis [Nirchio et al., 2007].

Multiple NORs are diversified even more drastically in the analyzed genera of other subfamilies and in many incertae sedis species of Characidae. Thus, rDNA sites are conserved in the pericentromeric region of 1 marker chromosome in 5 congeneric Astyanax species [AlmeidaToledo et al., 2002], but Astyanax scabripinnis $(2 \mathrm{n}=46-$ 50 ), which is considered to be a species complex now [Mantovani et al., 2005], has the largest number of rDNA sites described in Characidae (up to 16 FISH signals) [Ferro et al., 2000; Almeida-Toledo et al., 2002; Peres et al., 2008]. The genus Oligosarcus, closely related to Astyanax, has a uniform karyotype with $2 \mathrm{n}=50$ chromosomes, but shows a conspicuous interspecific variation in rDNA patterns. Thus, in O. hepsetus, 1 major rDNA site and an additional inactive site are located on the short arms of 2 distinct chromosome pairs, while O. jenynsii and O. pintoi show up to 8 rDNA clusters [Kavalco et al., 2005b; Centofante et al., 2006]. Also, conspicuous variation in the number of rDNA sites characterizes 2 analyzed species of Serrapinnus (Cheirodontinae) - 1 rDNA site in S. heterodon and 3-4 sites (7 FISH signals) in S. piaba [Peres et al., 2008] - while Hyphessobrycon luetkenii and $H$. anisitsi (both $2 \mathrm{n}=50$, but noticeably diverse in formulae) show 3-4 and more than 6 rDNA-bearing chromosome pairs, respectively [Mendes et al., 2011].

In the family Erythrinidae, species of the most extensively studied genus Hoplias show marked karyotype diversity. The 2 species, $H$. intermedius and $H$. aimara, have identical $2 \mathrm{n}=50$ karyotypes, but 1 and 2 rDNA-bearing chromosome pairs, respectively [Blanco et al., 2011]. In contrast, in $H$. malabaricus $(2 \mathrm{n}=40 / 42)$, the number of NOR-bearing chromosomes ranges from 4 to 7 [Born and Bertollo, 2000; Cioffi et al., 2009]. The species of Prochilodontidae have similar karyotypes, but up to 3 additional terminal rDNA sites were found in only 1 of the 2 species studied, Prochilodus argenteus [Hatanaka and Galetti, 2004].
On the whole, available data for characid-like fishes likely indicate that considerable variation in multiple rDNA patterns among related species are not necessarily related to chromosome macrorearrangements.

Among Cypriniformes, species with multiple rDNA loci are distributed in a rather patchy way, but data suitable for interspecific analysis may be found only in Cobitidae and Cyprinidae. Thus, in the representative species of 2 genera of bitterlings (Acheilognathinae, Cyprinidae), Rhodeus and Tanakia, which all show the ancestral $2 \mathrm{n}=$ 48 and $\mathrm{FN}=76$ karyotype, only $R$. ocellatus kurumeus has a single rDNA site, whereas the congeneric $R$. amarus and the related T. limbata [Sola et al., 2003] both present additional and variable rDNA sites; the number of rDNAbearing chromosomes may reach 7 , as in $R$. amarus [Libertini et al., 2008]. The Leuciscinae genera Squalius and Chondrostoma s.l. represent an extremely intricate case of rDNA systems, most certainly as a result of interspecific hybridization and polyploidization [Gromicho et al., 2005, 2006a, b; Pereira et al., this issue]. Finally, the genus Tor (incertae sedis) exemplifies a remarkable expansion of multiple rDNA systems in Cypriniformes. The species of this genus show tetraploid, $4 \mathrm{n}=100$, karyotypes with different chromosomal formulae, while rDNA sites are located on 2 chromosome pairs in T. khudree and T. mussullah and on 3 apparently different chromosome pairs in T. mosal mahanadicus, T. chelynoides, T. putitora, and T. progeneius, whereas T. tor (which inhabits a different environmental niche) shows no less than 10 FISH signals for rDNA and most of the multiple rDNA sites are inactive (silent and cryptic, see hereinafter) in these species [Singh et al., 2009; Mani et al., 2011].

While most catfishes (Siluriformes) studied so far have single rDNA sites [Sczepanski et al., 2010], the genus $\mathrm{Hy}$ postomus (Loricariidae, Hypostominae) represents a resounding exception [Kavalco et al., 2005a; Rubert et al., 2011; Alves et al., 2012]. All rDNA sites in 6 Hypostomus species are located on either centromeric or distal termini of subtelo-/acrocentric chromosomes which is considered derived from the basal location proposed for the Siluriformes [Oliveira and Gosztonyi, 2000]. However, the variation in rDNA site distribution is not apparently related to the evolutionary karyotype rearrangements by means of centric fusions/fissions and pericentric inversions [Artoni and Bertollo, 2001].

Very stimulating data have been gained in protacanthopterygian fishes: in all 3 subfamilies of the Salmonidae (Salmoniformes) - Coregoninae, Salmoninae and Thymallinae - as well as in the small family Umbridae (Esociformes) with only 5 assigned species of the genus UmDOI: $10.1159 / 000354832$
Gornung 
bra. In this latter family, 2 North American species of the genus, U. limi and U. pygmaea, have identical all-metacentric karyotypes $(2 \mathrm{n}=22)$, originated by Robertsonian fusions, and show major rDNA sites on homeologous chromosome pairs, though in different positions due to a pericentric inversion [Ráb et al., 2002]. The pericentromeric NORs of $U$. pygmaea, according to the authors, likely represent a primitive feature since a similar pattern was revealed, by classical methods, in the European $U$. krameri and in the distantly related genus Esox [Ráb and Crossman, 1994]. However, the additional rDNA sites are distributed in a distinct and quite peculiar mode in the 2 Umbra species and, among other things, the authors hypothesize involvement of a mobile element in dislocation of rDNA [Ráb et al., 2002].

The salmonid fishes have evolved from a hypothetical tetraploid ancestor by 2 modes of chromosome evolution, that is, by mainly Robertsonian fusions or mainly inversions and small tandem translocations, resulting in occurrence of 2 classes of karyotypes: (1) close to $2 n=80$, $\mathrm{NF}=100$ and (2) close to $2 \mathrm{n}=60, \mathrm{NF}=100$ [Frolov, 2000; Phillips and Ráb, 2001]. Although the first mode prevails in the Coregoninae and the Salmoninae and the second one characterizes Thymallinae, at least 1 discordant example is found in any genera. In the subfamily Coregoninae - the earliest lineage evolved from a common ancestor of salmonids - multiple rDNA sites have been described in the 3 European Coregonus species, C. peled, $C$. albula and C. lavaretus $(2 \mathrm{n}=80)$ [Jankun et al., 2000, 2001]. In either species, the major rDNA sites are located on likely homeologous chromosomes, and there are also several additional small and rarely active rDNA sites on up to 4 chromosome pairs, as in 1 population of C. lavaretus [Rossi and Gornung, 2005]. All rDNA sites are located terminally on the short arms of subtelo-/acrocentric chromosomes. All minor rDNA clusters mark heterochromatic regions of the short arms of acrocentric chromosomes. The inter- and intraspecific variation regards these minor sites. In Salmoninae, many species, even those with $2 \mathrm{n}=80$ and higher $2 \mathrm{n}$ values, have single-site NORs detected by FISH [Reed and Phillips, 1995; Fujiwara et al., 1998; Alonso et al., 1999; Ocalewicz et al., 2008]. Nevertheless, invariable major rDNA sites and additional variable ones (often present in heterozygous condition) have been reported in other species [Fujiwara et al., 1998; Jankun et al., 2003]. Multichromosomal locations of rDNA are patterned species-specifically in most of the Salvelinus species [Reed and Phillips, 1995, 1997; Phillips et al., 2002]. Thus, the number of additional nonactive rDNA sites may be just one, as in S. alpinus [Reed and Phillips, 1997] or may amount to 29-50 (in terms of FISH signals), as it occurs in S. frontalis [Fujiwara et al., 1998].

Furthermore, the 2 different patterns, single-site or multiple, may occur in 2 closely related species. Thus, $\mathrm{Sal}-$ mo salar $(2 \mathrm{n}=58, \mathrm{NF}=74)$ presents only $1 \mathrm{rDNA}$-bearing chromosome pair with rDNA widely dispersed in the heterochromatin of polymorphic chromosome arms [Pendás et al., 1993b], whereas S. trutta exhibits additional transcriptionally inactive rDNA sites on as much as 8 [Pendás et al., 1993a] or even 9 [Caputo et al., 2009] chromosome pairs. The occurrence of vastly extended regions bearing rDNA in such species as Salmo salar, Oncorhynchus mykiss, O. masou, and Hucho perryi, and abundant rDNA loci in other species, as well as the limited gene activation among them, are thought to be associated with local amplification/segmental duplication of NORs, proximity of heterochromatin and, most probably, regulation by epistatic mechanisms of intra-/interlocus dominance [Fujiwara et al., 1998; Jankun et al., 2003]. To explain the dual variability of rDNA loci in several salmonid species, Fujiwara et al. [1998] proposed the idea of 'bidirectional evolution', i.e. accumulation versus dispersion of rDNA clusters in Salmonidae. Selection for increases or decreases in genetic recombination may account for the extraordinary situation in the Salmonidae according to Phillips and Reed [2000].

Within Percomorpha, the first interspecific valuation of multiple rDNA site systems was performed in Synbranchiformes [Carvalho et al., 2012] and in Syngnathiformes [Vitturi et al., 1998; Libertini et al., 2006]. Among Cyprinodontiformes, multiple rDNA sites have been detected only in Aphanius fasciatus [Vitturi et al., 2005] and Xiphophorus maculatus [Ocalewicz, 2004]. These data look promising and undoubtedly need further development. Among 32 cichlid species of both African and South American clades so far analyzed, the number of rDNA-bearing chromosome pairs varies from 1 to 3 , and the great majority of rDNA clusters are present at terminal locations [reviewed in Nakajima et al., 2012]. The genus Symphysodon (Cichlidae, Cichlasomatinae) [Gross et al., 2010] and several species of Pseudocrenilabrinae [Poletto et al., 2010a, b; Fantinatti et al., 2011] show greater genomic dynamism of rDNA, and the authors discuss a possibility of amplification/dispersion of rDNA segments by transposition events, with participation of extrachromosomal circular DNA and transposable elements, and/ or heterologous recombination favored by terminal location of rDNA. 


\section{Dynamics and Polymorphisms of rDNA Sites}

As corroborated herein, the most frequent condition $(\sim 72 \%)$ in teleosts is a single rDNA-bearing chromosome pair per diploid karyotype, which suggests that the number of rDNA sites generally tends to be restricted. The causes of structural rearrangements and relocation of rDNA sites are thought to be prompted by several modifying factors. Homogenization of rDNA arrays, ensuring the removal of non-functional rDNA units, which is a fundamental process to reduce the intraindividual variability of this key molecule, may, however, lead to a particular state of NORs, namely disproportion in homologous sites leading to so-called chromosome heteromorphism, which is quite common in fishes, e.g. salmonids [Pendás et al., 1993b; Reed and Phillips, 1997], the Antarctic notothenioid fishes [Pisano and Ghigliotti, 2009] or the mugilid O. labeo [Rossi et al., 2000]. Different amounts of gene units in the rDNA loci is an important feature of heteromorphic chromosomes, but heteromorphism may be facilitated, directly or indirectly, by constitutive heterochromatin associated with the rDNA and commonly believed to be related to transcriptional regulation of rRNA genes. Heterochromatic regions are known to harbor various types of repetitive sequences in fishes [reviewed in Cioffi and Bertollo, 2012]: some repeats may promote rearrangements via non-allelic homologous recombination, while the association with others reflects the instability of particular genomic regions [Coghlan et al., 2005]. Thus, multiple copies of telomeric repeats scattered within the NOR-associated heterochromatin or bordering rDNA sites may act as recombination hot spots, as hypothesized for some fish species [e.g. Salvadori et al., 1995; Sola et al., 2003]. However, it is worth noting that in rare instances, such as Cobitis vardarensis, rDNA apparently is not associated with heterochromatin [Rábová et al., 2001].

Chromosomal macrorearrangements, i.e. rearrangements of the linkage groups, such as translocations or inversions, may account for many events of relocation/loss of single rDNA sites within and among chromosomes in most lineages analyzed to date. On the other hand, in the so far available studies of species with multiple and variable rDNA sites, transposition of a few rRNA genes to new chromosome locations was hypothesized. A few weighty studies determining rDNA variants at multiple chromosomal sites in fishes [e.g. Zhuo et al., 1995] support this idea. The mobility of rDNA without structural rearrangements was originally proposed in plants, as the 'dispersion-amplification-deletion' model [Dubcovsky and Dvorák, 1995], according to which rDNA sites may change position in the chromosomes through amplification of the neo-inserted minor loci, consisting of a few rDNA copies or even single ribosomal gene orphon-like sequences [Schubert and Wobus, 1985]. According to the authors, original major sites may subsequently be suppressed and/or deleted because of their hypostatic state. Concurrently, unequal crossing over can magnify the minor rDNA loci to become major rDNA sites.

As substantiated above, the major $\mathrm{rDNA}$ sites in fishes are mainly $(\sim 87 \%)$ found in, and contiguous to, the terminal regions of chromosomes. It seems that the terminal position of the rDNA loci is an important condition, not only because it determines a greater degree of concerted evolution and allows frequent rearrangements to occur without disrupting other gene linkages in the karyotype [Hanson et al., 1996], but also because it promotes genetic material relocation due to the proximity of telomeres within the interphase nucleus.

The reinsertion of circular intermediates and mobile genetic elements closely linked to rDNA has been proposed as a molecular mechanism of rDNA dispersion [reviewed in Reed and Phillips, 2000]. The remarkable role of transposable elements in mediating chromosome rearrangements and generating genome plasticity, potentially associated with speciation, is widely acknowledged [reviewed in Bohne et al., 2008], but a direct involvement of transposons $(\mathrm{En} / \mathrm{Spm})$ in rDNA dispersion through the genome has been demonstrated in Aegilops speltoides (Poaceae) [Raskina et al., 2004]. In teleosts, rDNA transposition tentatively accounts for several cases of intraspecific NOR variation in fishes, such as, for example, poeciliids [Sola et al., 1990] and salmonids [reviewed in Reed and Phillips, 2000]. The occurrence of Tc1-like transposons in Salvelinus namaycush [Reed, 1999] and Chionodraco hamatus [Capriglione et al., 2002] and effective association of mariner-type transposable elements and NORs in Tetraodon fluviatilis and Gobius niger [Mandrioli, 2000; Mandrioli et al., 2000b] support these possibilities.

Furthermore, polymorphisms related to transcriptional inactivation of rDNA sites are widespread in fishes. Two categories of inactive sites are recurrently reported: the silent ones, probably corresponding to the rDNA loci in the process of elimination, and the cryptic ones, which likely correspond to novel, low-copy number, minor rDNA loci [Mani et al., 2011]. The rDNA elimination and gene silencing through DNA methylation or induced by neighboring heterochromatin (position effect) may account for inactivation of rDNA sites [Guillén et al., 2004; Cabrero and Camacho, 2008]. Actually, association of
98

Cytogenet Genome Res 2013;141:90-102 DOI: $10.1159 / 000354832$
Gornung 
rDNA sites with As51 satellite DNA, probably originated from a transposable element, was found to induce rDNA silencing in the genus Astyanax [Vicari et al., 2008]. It is worth noting that, in contrast, the presence of active sites on both female X chromosomes in Hoplias malabaricus shows that the rRNA genes are not subjected to a mechanism of X inactivation [Cioffi et al., 2009].

The tough question is why some species manifest a pronounced polymorphism of rDNA systems and others do not? We are still far from understanding this, but some indications are emerging. Thus, the transposition rate, which is believed to play a key role in rDNA dispersion, is somehow controlled by the frequency of permissive host alleles, natural selection that opposes accumulation of transposable elements and population size [Nuzhdin, 1999]. Under these lines, the diffusion of multiple and variable rDNA systems among neotropical freshwater fishes is symptomatic. In contrast, the decreased levels of genetic variation among marine populations, the general conservativeness of karyotypes, with significant exceptions of particular taxa, such as the reef fishes [Molina and Galetti, 2004], is in correlation with single-site and invariable rDNA systems.
Applying the 45S rDNA FISH data on the current fish phylogeny [Nakatani et al., 2011 and references therein], it is evident that karyotypes with multiple rDNA sites appear mosaically in paraphyletic assemblages (e.g. Perciformes, Labroidei) and in distant monophyletic clades. It looks like this phenomenon reflects particular dynamic properties of specific genomes in the course of ongoing adaptive evolution. An impression emerges from these studies: it seems that the cytogenetic mapping of rDNA may not reflect simply the evolutionary history of lineages, but the intense and particular evolutionary pathways of some taxa [see Nakajima et al., 2012].

\section{Acknowledgements}

I am grateful to Riccardo Castiglia for critical reading of this paper. I also wish to express my gratitude to the 'Charles Darwin' Department of the University 'La Sapienza' for continuously supporting my research projects and to Luciana Sola and her group, with whom collaboration in the past made the present effort possible.

\section{References}

-Almeida-Toledo LF, Foresti F, Toledo-Filho SA: Karyotypic evolution of neotropical freshwater fish, in Olmo E, Redi CA (eds): Chromosomes Today, vol 13, pp 169-182 (Birkhäuser Verlag, Basel 2000).

Almeida-Toledo LF, Ozouf-Costaz C, Foresti F, Bonillo C, Porto-Foresti F, Daniel-Silva MFZ: Conservation of the 5S-bearing chromosome pair and co-localization with major rDNA clusters in five species of Astyanax (Pisces, Characidae). Cytogenet Genome Res 97:229233 (2002).

-Alonso M, Fujiwara A, Yamaha E, Kimura S, Abe $S$ : Ribosomal RNA gene loci and silver-stained nucleolar organizer regions associated with heterochromatin in Alaskan char Salvelinus malma and chum salmon Oncorhynchus keta. Hereditas 131:221-225 (1999).

- Alves AL, de Borba RS, Pozzobon APB, Oliveira C, Nirchio M, et al: Localization of $18 \mathrm{~S}$ ribosomal genes in suckermouth armoured catfishes Loricariidae (Teleostei, Siluriformes) with discussion on the Ag-NOR evolution. Comp Cytogenet 6:315-321 (2012).

-Amemiya CT, Gold JR: Chromomycin A3 stains nucleolus organizer regions of fish chromosomes. Copeia 1986:226-231 (1986).

-Amemiya CT, Gold JR: Chromosomal NORs as taxonomic and systematic characters in North cyprinid fishes. Genetica 76:81-90 (1988).

Amemiya CT, Gold JR: Chromosomal NOR phenotypes of seven species of North American
Cyprinidae, with comments on cytosystematic relationships of the Notropis volucellus speciesgroup, Opsopoeodus emiliae, and the genus Pteronotropis. Copeia 1990:68-78 (1990).

-Arai R: Fish Karyotypes. A Check List (Springer, Tokyo 2011).

Artoni RF, Bertollo LAC: Trends in the karyotype evolution of Loricariidae fish (Siluriformes). Hereditas 134:201-210 (2001).

Bernardi G, Bernardi G: Compositional patterns in the nuclear genome of cold-blooded vertebrates. J Mol Evol 31:265-281 (1990).

Birstein VJ, Hanner R, Desalle R: Phylogeny of the Acipenseriformes: cytogenetic and molecular approaches. Envir Biol Fish 48:127-155 (1997).

- Blanco DR, Lui RL, Vicari MR, Bertollo LA, Moreira-Filho O: Comparative cytogenetics of giant trahiras Hoplias aimara and H. intermedius (Characiformes, Erythrinidae): chromosomal characteristics of minor and major ribosomal DNA and cross-species repetitive centromeric sequences mapping differ among morphologically identical karyotypes. Cytogenet Genome Res 132:71-78 (2011).

-Blanco DR, Vicari MR, Artoni RF, Traldi JB, Moreira-Filho O: Chromosomal characterization of armored catfish Harttia longipinna (Siluriformes, Loricariidae): first report of B chromosomes in the genus. Zoolog Sci 29: 604-609 (2012).

Bohne A, Brunet F, Galiana-Arnoux D, Schultheis C, Volff JN: Transposable elements as drivers of genomic and biological diversity in vertebrates. Chromosome Res 16:203-215 (2008).

Born GG, Bertollo LAC: An XX/XY sex chromosome system in a fish species, Hoplias malabaricus, with a polymorphic NOR-bearing $\mathrm{X}$ chromosome. Chromosome Res 8:111-118 (2000).

Cabrero J, Camacho JPM: Location and expression of ribosomal RNA genes in grasshoppers: abundance of silent and cryptic loci. Chromosome Res 16:595-607 (2008).

-Capriglione T, Odierna G, Caputo V, Canapa A, Olmo E: Characterization of a Tc1-like transposon in the Antarctic ice-fish, Chionodraco hamatus. Gene 295:193-198 (2002).

-Caputo V, Machella N, Nisi-Cerioni P, Olmo E: Cytogenetics of nine species of Mediterranean blennies and additional evidence for an unusual multiple sex-chromosome system in Parablennius tentacularis (Perciformes, Blenniidae). Chromosome Res 9:3-12 (2001).

Caputo V, Nisi Cerioni P, Splendiani A, Capriglione T, Odierna G, Olmo E: Chromosomal studies on ten species of notothenioid fishes (Notothenioidei: Bathydraconidae, Channichthyidae, Nototheniidae). Cytogenet Genome Res 98:285-290 (2002).

Caputo V, Giovannotti M, Nisi Cerioni P, Splendiani A, Olmo E: Chromosomal study of native and hatchery trouts from Italy (Salmo trutta complex, Salmonidae): conventional and FISH analysis. Cytogenet Genome Res 124:51-62 (2009).
Chromosomal Mapping of rDNA in Teleosts
Cytogenet Genome Res 2013;141:90-102 DOI: $10.1159 / 000354832$ 
Carvalho NDM, Gross MC, Schneider CH, Terencio ML, Zuanon J, Feldberg E: Cytogenetics of Synbranchiformes: a comparative analysis of two Synbranchus Bloch, 1795 species from the Amazon. Genetica 140:149-158 (2012).

Carvalho de Azevedo MF, Oliveira C, Pardo BG, Martínez P, Foresti F: Chromosome banding and $18 \mathrm{~S}$ rDNA in situ hybridization analysis of seven species of the family Achiridae (Teleostei: Pleuronectiformes). Genetica 125: 125-132 (2005).

-Centofante L, Bertollo LA, Moreira-Filho O: Chromosomal differentiation between populations of Oligosarcus hepsetus (Teleostei, Characidae) from small tributaries at opposite margins of the Paraíbo do Sul river (Brazil). Brazil Arch Biol Technol 49:981-987 (2006).

-Cioffi MB, Bertollo LAC: Chromosomal distribution and evolution of repetitive DNAs in fish. Genome Dyn 7:197-221 (2010).

-Cioffi MB, Bertollo LAC: Chromosomal distribution and evolution of repetitive DNAs in fish, in Garrido-Ramos MA (ed): Repetitive DNAs. Cytogenet Genome Res 7:197-221 (2012).

-Cioffi MB, Martins C, Bertollo LAC: Comparative chromosome mapping of repetitive sequences. Implications for genomic evolution in the fish, Hoplias malabaricus. BMC Genet 10:34 (2009).

-Cioffi M, Kejnovský E, Marquioni V, Poltronieri J, Molina WF, et al: The key role of repeated DNAs in sex chromosome evolution in two fish species with ZW sex chromosome system. Mol Cytogenet 5:28 (2012).

-Coghlan A, Eichler EE, Oliver SG, Paterson AH, Stein L: Chromosome evolution in eukaryotes: a multi-kingdom perspective. Trends Genet 21:673-682 (2005).

Coluccia E, Cannas R, Milia A, Deiana AM, Salvadori S: Localization of the ribosomal genes in Anguilliformes (Chordata, Osteichthyes). Ann Genet 44 (S1):41 (2001).

-Coluccia E, Deiana AM, Libertini A, Salvadori S: Cytogenetic characterization of the moray eel Gymnothorax tile and chromosomal banding comparison in Muraenidae (Anguilliformes). Mar Biol Res 6:106-111 (2010).

da Rosa R, Rubert M, Caetano-Filho M, GiulianoCaetano L: Conserved cytogenetic features in the Amazonian Arapaima, Arapaima gigas (Schinz 1822) from Jamari River, RondôniaBrazil. Open Biol J 2:91-94 (2009).

da Silva EL, Busso AF, Parise-Maltempi PP: Characterization and genome organization of a repetitive element associated with the nucleolus organizer region in Leporinus elongatus (Anostomidae: Characiformes). Cytogenet Genome Res 139:22-28 (2013).

Deiana AM, Coluccia E, Cannas R, Pesci P, Fonnesu A, Salvadori S: Colocalization of the ribosomal gene families in Conger conger (Anguilliformes, Congridae). Ital J Zool 73:1-5 (2006).

Diniz D, Laudicina A, Bertollo LA: Chromosomal location of $18 \mathrm{~S}$ and $5 \mathrm{~S}$ rDNA sites in Triportheus fish species (Characiformes, Characidae). Genet Mol Biol 32:37-41 (2009).
Dobigny G, Ozouf-Costaz C, Bonillo C, Volobouev V: 'Ag-NORs' are not always true NORs: new evidence in mammals. Cytogenet Genome Res 98:75-77 (2002).

Dubcovsky J, Dvorák J: Ribosomal RNA multigene loci: nomads of the Triticeae genomes. Genetics 140:1367-1377 (1995).

Eickbush TH, Eickbush DG: Finely orchestrated movements: evolution of the ribosomal RNA genes. Genetics 175:477-485 (2007).

Elder JF Jr, Turner BJ: Concerted evolution of repetitive DNA sequences in eukaryotes. Q Rev Biol 70:297-320 (1995).

Escobar JS, Glémin S, Galtier N: GC-biased gene conversion impacts ribosomal DNA evolution in vertebrates, angiosperms, and other eukaryotes. Mol Biol Evol 28:2561-2575 (2011).

-Fantinatti BE, Mazzuchelli J, Valente GT, Cabralde-Mello DC, Martins C: Genomic content and new insights on the origin of the $\mathrm{B}$ chromosome of the cichlid fish Astatotilapia latifasciata. Genetica 139:1273-1282 (2011).

-Ferro DAM, Néo DM, Bertollo LAC: Nucleolar organizing regions, $18 \mathrm{~S}$ and $5 \mathrm{~S}$ rDNA in Astyanax scabripinnis (Pisces, Characidae): populations distribution and functional diversity. Genetica 110:55-62 (2000).

- Fontana F, Tagliavini J, Congiu L, Lanfredi M, Chicca M, et al: Karyotypic characterization of the great sturgeon, Huso huso, by different staining techniques and fluorescent in situ hybridization with 28S, $5 \mathrm{~S}$ rDNA genes and telomeric sequences. Mar Biol 132:495-501 (1998).

-Fontana F, Lanfredi M, Congiu L, Leis M, Chicca M, Rossi R: Chromosomal mapping of 18S$28 \mathrm{~S}$ and $5 \mathrm{~S}$ rRNA genes by two-colour fluorescent in situ hybridization in six sturgeon species. Genome 46:473-477 (2003).

Fontana F, Bruch RM, Binkowski FP, Lanfredi M, Chicca M, et al: Karyotype characterization of the lake sturgeon, Acipenser fulvescens (Rafinesque 1817) by chromosome banding and fluorescent in situ hybridization. Genome 47: 742-746 (2004).

Frolov SV: Karyotype variability and evolution in Salmonidae [in Russian], in Kasianov VL (ed): FED. RAS (Dalnauka, Vladivostok, 2000).

Fujiwara A, Abe S, Yamaha E, Yamazaki F, Yoshida MC: Chromosomal localization and heterochromatin association of ribosomal RNA gene loci and silver-stained nucleolar organizer regions in salmonid fishes. Chromosome Res 6:463-471 (1998).

Garcia C, Moreira Filho O: Cytogenetical analyzes in three fish species of the genus Pimelodus (Siluriformes: Pimelodidae) from rio São Francisco: considerations about the karyotypical evolution in the genus. Neotrop Ichthyol 3:285-290 (2005).

Garcia C, Moreira Filho O: Localization of ribosomal genes in three Pimelodus species (Siluriformes, Pimelodidae) of the São Francisco River: $5 S$ genes as species markers and conservation of the $18 \mathrm{~S}$ rDNA sites. Genet Mol Biol 31:261-264 (2008).
Ghigliotti L, Mazzei F, Ozouf-Costaz C, Bonillo C, Williams R, et al: The two giant sister species of the Southern Ocean, Dissostichus eleginoides and Dissostichus mawsoni, differ in karyotype and chromosomal pattern of ribosomal RNA genes. Polar Biol 30:625-634 (2007).

Ghigliotti L, Møller PR, Cheng CH, Christiansen JS, Fevolden SE, Pisano E: Exploring the diversity of Arctic eelpouts: first cytogenetic data on species of the genus Lycodes (Teleostei, Zoarcidae). Mar Genomics 8:35-41 (2012).

Goodpasture C, Bloom SE: Visualisation of the nucleolus organizer regions in mammalian chromosomes using silver staining. Chromosoma 53:37-50 (1975).

-Gornung E, Gabrielli I, Cataudella S, Sola L: $\mathrm{CMA}_{3}$-banding pattern and fluorescence in situ hybridization with $18 \mathrm{~S}$ rRNA genes in zebrafish chromosomes. Chromosome Res 5: 40-46 (1997).

Gromicho M, Ozouf-Costaz C, Collares-Pereira $\mathrm{MJ}$ : Lack of correspondence between $\mathrm{CMA}_{3}$, Ag-positive signals and 28S rDNA loci in two Iberian minnows (Teleostei, Cyprinidae) evidenced by sequential banding. Cytogenet Genome Res 109:507-511 (2005).

Gromicho M, Coutanceau JP, Ozouf-Costaz C, Collares-Pereira MJ: Contrast between extensive variation of $28 \mathrm{~S}$ rDNA and stability of $5 \mathrm{~S}$ rDNA and telomeric repeats in the diploidpolyploid Squalius alburnoides complex and in its maternal ancestor Squalius pyrenaicus (Teleostei, Cyprinidae). Chromosome Res 14: 297-306 (2006a).

Gromicho M, Coelho MM, Alves MJ, CollaresPereira MJ: Cytogenetic analysis of Anaecypris hispanica and its relationship with the paternal ancestor of the diploid-polyploid Squalius alburnoides complex. Genome 49: 1621-1627 (2006b).

- Gross MC, Schneider CH, Valente GT, Martins C, Feldberg E: Variability of $18 \mathrm{~S}$ rDNA locus among Symphysodon fishes: chromosomal rearrangements. J Fish Biol 76:1117-1127 (2010).

-Guillén AK, Hirai Y, Tanoue T, Hirai H: Transcriptional repression mechanisms of nucleolus organizer regions (NORs) in humans and chimpanzees. Chromosome Res 12:225-237 (2004).

-Hanson RE, Islam-Faridi MN, Percival EA, Crane CF, Ji Y, et al: Distribution of 5 S and 18S-28S rDNA loci in a tetraploid cotton (Gossypium hirsutum L.) and its putative diploid ancestors. Chromosoma 105:55-61 (1996).

Hatanaka T, Galetti PM: Mapping of the $18 \mathrm{~S}$ and $5 \mathrm{~S}$ ribosomal RNA genes in the fish Prochilodus argenteus Agassiz, 1829 (Characiformes, Prochilodontidae), Genetica 122:239-244 (2004).

Howell WM, Black AD: Controlled silver staining of nucleolus organizer regions with a protective colloidal developer: a 1-step method. Experientia 36:1014-1015 (1980).

-Jankun M, Martinez P, Pardo BG, Ráb P, Rábová M, Sanchez L: rRNA genes map to chromosomes 10, 11 and 12 in European whitefish (Coregonus lavaretus) and to chromosome 1, 5, 9 and 10 in vendace (Coregonus albula). Chromosome Res 8:455 (2000). 
-Jankun M, Martinez P, Pardo BG, Kirtiklis L, Ráb $\mathrm{P}$, et al: Ribosomal genes in coregonid fishes (Coregonus lavaretus, C. albula, and C. peled) (Salmonidae): single and multiple nucleolus organizer regions. Heredity 87:672-679 (2001).

-Jankun M, Ocalewicz K, Pardo BG, Martinez P, Woznicki P, Sanchez L: Chromosomal characteristics of rDNA in European grayling Thymallus thymallus (Salmonidae). Genetica 119:219-224 (2003).

-Ji FY, Yu QX, Li K, Ren XH: Ag-staining pattern, FISH and ISH with rDNA probes in the rice field eel (Monopterus albus Zuiew) chromosomes. Hereditas 138:207-212 (2003).

-Kavalco KF, Pazza R, Bertollo LA, Moreira-Filho O: Karyotypic diversity and evolution of Loricariidae (Pisces, Siluriformes). Heredity 94: 180-186 (2005a).

-Kavalco KF, Pazza R, Bertollo LAC, Moreira-Filho O: Molecular cytogenetics of Oligosarcus hepsetus (Teleostei, Characiformes) from two Brazilian locations. Genetica 124:85-91 (2005b).

Klinkhardt M, Tesche M, Greven H: Database of Fish Chromosomes (Westarp Wissenschaften, Magdeburg 1995).

- Koehler MR, Dehm D, Guttenbach M, Nanda I, Haaf T, et al: Cytogenetics of the genus Leporinus (Pisces, Anostomidae). 1. Karyotype analysis, heterochromatin distribution and sex chromosomes. Chromosome Res 5:12-22 (1997).

Liao D: Concerted evolution: molecular mechanism and biological implications. Am J Hum Genet 64:24-30 (1999).

Libertini A, Vitturi R, Lannino A, Maone MC, Franzoi $\mathrm{P}$, et al: FISH mapping of $18 \mathrm{~S}$ rDNA and (TTAGGG)n sequences in two pipefish species (Gasteroisteiformes: Syngnathidae). J Genet 85:153-156 (2006).

- Libertini A, Sola L, Rampin M, Rossi AR, Iijima $\mathrm{K}$, et al: Classical and molecular cytogenetic characterization of allochthonous European bitterling Rhodeus amarus (Cyprinidae, Acheilognathinae) from northern Italy. Genes Genet Syst 83:417-422 (2008).

Mandrioli M: Mariner-like transposable elements are interspersed within the rDNA-associated heterochromatin of the pufferfish Tetraodon fluviatilis (Osteichthyes). Chromosome Res 8: 177-179 (2000).

-Mandrioli M, Colomba MS, Vitturi R: Chromosomal analysis of repeated DNAs in the rainbow wrasse Coris julis (Pisces, Labridae). Genetica 108:191-195 (2000a).

- Mandrioli M, Manicardi GC, Machella N, Caputo $\mathrm{V}$ : Molecular and cytogenetic analysis of the goby Gobius niger (Teleostei, Gobiidae). Genetica 110:73-78 (2000b).

-Mani I, Kumar R, Singh M, Nagpure NS, Kushwaha B, et al: Nucleotide variation and physical mapping of ribosomal genes using FISH in genus Tor (Pisces, Cyprinidae). Mol Biol Rep 384:2637-2647 (2011).

-Mantovani M, Dos Santos Abel LD, Moreira-Filho O: Conserved 5S and variable $45 \mathrm{~S}$ rDNA chromosomal localisation revealed by FISH in Astyanax scabripinnis (Pisces, Characidae). Genetica 123:211-216 (2005)

Mariguela TC, Nirchio M, Ron E, Gaviria JI, Foresti F, Oliveira C: Cytogenetic characterization of Brycon amazonicus (Spix et Agassiz, 1829) (Teleostei: Characidae) from Caicara del Orinoco, Venezuela. Comp Cytogenet 4: 185-193 (2010).

Marques DK, Venere PC, Galetti PM Jr: Chromosomal characterization of the bonytongue Arapaima gigas (Osteoglossiformes, Arapaimidae). Neotrop Ichthyol 4:215-218 (2006).

Martínez JL, Morán P, García-Vázquez E, Pendás AM: Chromosomal localization of the major and 5S rRNA genes in the European eel (Anguilla anguilla). Cytogenet Cell Genet 73:149152 (1996).

Martinez PA, de Araujo WC, Molina WF: Derived cytogenetic traits, multiple NORs and $\mathrm{B}$ chromosomes in the compact karyotype of Canthigaster figueiredo (Tetraodontiformes). Mar Genomics 3:85-89 (2010).

Mayr B, Rab P, Kalat M: Nucleolar organizing regions and counterstain-enhanced fluorescence studies in Cyprinidae of different ploidy level. Genetica 69:111-118 (1986).

Mazzei F, Ghigliotti L, Bonillo C, Coutanceau J-P, Ozouf-Costaz C, Pisano E: Chromosomal patterns of major and $5 \mathrm{~S}$ ribosomal DNA in six icefish species (Perciformes, Notothenioidei, Channichthyidae). Polar Biol 28:47-55 (2004).

-Mazzei F, Ghigliotti L, Lecointre G, Ozouf-Costaz C, Coutanceau J-P, et al: Karyotypes of basal lineages in notothenioid fishes: the genus Bovichtus. Polar Biol 29:1071-1076 (2006).

-Mendes MM, da Rosa R, Giuliano-Caetano L, Dias AL: Karyotype diversity of four species of the incertae sedis group (Characidae) from different hydrographic basins: analysis of $\mathrm{Ag}$ NORs, $\mathrm{CMA}_{3}$ and $18 \mathrm{~S}$ rDNA. Genet Mol Res 10:3596-3608 (2011).

-Merlo MA, Cross I, Manchado M, Cárdenas S, Rebordinos L: The 5S rDNA high dynamism in Diplodus sargus is a transposon-mediated mechanism. Comparison with other multigene families and Sparidae species. J Mol Evol 76:83-97 (2013).

Molina WF, Galetti PM: Multiple pericentric inversions and chromosome divergence in (Perciformes, Pomacentridae). Genet Mol Biol 27:543-548 (2004).

Morescalchi MA, Stingo V, Capriglione T: Cytogenetic analysis in Polypterus ornatipinnis (Actinopterygii, Cladistia, Polypteridae) and 5S rDNA. Mar Genomics 4:25-31 (2011).

Nagylaki T: Evolution of multigene families under interchromosomal gene conversion. Proc Natl Acad Sci USA 81:3796-3800 (1984).

- Nakajima RT, Cabral-de-Mello DC, Valente GT, Venere PC, Martins C: Evolutionary dynamics of rRNA gene clusters in cichlid fish. BMC Evol Biol 12:198 (2012).

- Nakatani M, Miya M, Mabuchi K, Saitoh K, Nishida M: Evolutionary history of Otophysi (Teleostei), a major clade of the modern freshwater fishes: Pangaean origin and Mesozoic radiation. BMC Evol Biol 11:177 (2011).
Nei M, Rooney AP: Concerted and birth-anddeath evolution of multigene families. Annu Rev Genet 39:121-152 (2005).

Nelson JS: Fishes of the World, ed 4 (John Wiley \& Sons, Inc., Hoboken 2006).

Nirchio M, Oliveira C, Ferreira IA, Granado A, Ron E: Extensive polymorphism and chromosomal characteristics of ribosomal DNA in the characid fish Triportheus venezuelensis (Characiformes, Characidae). Genet Mol Biol 30:25-30 (2007).

Nuzhdin SV: Sure facts, speculations, and open questions about the evolution of transposable element copy number. Genetica 107:129-137 (1999).

-Ocalewicz K: Cytogenetic analysis of platyfish (Xiphophorus maculatus) shows location of major and minor rDNA on chromosomes. Hereditas 141:333-337 (2004).

Ocalewicz K, Woznicki P, Jankun M: Mapping of rRNA genes and telomeric sequences in Danube salmon (Hucho hucho) chromosomes using primed in situ labeling technique (PRINS). Genetica 134:199-203 (2008).

-Oliveira C, Gosztonyi AE: A cytogenetic study of Diplomystes mesembrinus (Teleostei, Siluriformes, Diplomystidae) with a discussion of chromosome evolution in Siluriformes. Caryologia 53:31-37 (2000).

Ozouf-Costaz C, Pisano E, Thaeron C, Hureau J-C: Antarctic fish chromosome banding: significance for evolutionary studies. Cybium 21:399-409 (1997).

Pendás AM, Moran P, Garcia-Vasquez E: Multichromosomal location of ribosomal RNA genes and heterochromatin association in brown trout. Chromosome Res 1:63-67 (1993a).

Pendás AM, Moran P, Garcia-Vasquez E: Ribosomal RNA genes are interspersed throughout a heterochromatic chromosome arm in Atlantic salmon. Cytogenet Cell Genet 63: 128-130 (1993b).

Peng Z, Diogo R, He S: Teleost fishes (Teleostei), in Hedges SB, Kumar S (eds): Timetree of Life, pp 335-338 (Oxford University Press, Oxford 2009).

- Peres WAM, Bertollo LAC, Moreira Filho O: Physical mapping of the $18 \mathrm{~S}$ and $5 \mathrm{~S}$ ribosomal genes in nine Characidae species (Teleostei, Characiformes). Genet Mol Biol 31:222-226 (2008).

Phillips RB, Ráb P: Chromosome evolution in the Salmonidae (Pisces): an update. Biol Rev 76: 1-25 (2001).

Phillips RB, Reed KM: Localization of repetitive DNAs to zebrafish (Danio rerio) chromosomes by fluorescence in situ hybridization (FISH). Chromosome Res 8:27-35 (2000).

Phillips RB, Gudex LI, Westrich KM, DeCicco A: Combined phylogenetic analysis of ribosomal ITS1 sequences and new chromosome data supports three subgroups of Dolly Varden char (Salvelinus malma). Can J Fish Aquat Sci 56:1504-1511 (1999).

Phillips RB, Matsuoka MP, Reed KM: Characterization of char chromosomes using fluorescence in situ hybridization. Environ Biol Fish 64:223-228 (2002)
Chromosomal Mapping of rDNA in Teleosts
Cytogenet Genome Res 2013;141:90-102 DOI: $10.1159 / 000354832$ 
-Pisano E, Ghigliotti L: Ribosomal genes in notothenioid fishes: focus on the chromosomal organisation. Mar Genomics 2:75-80 (2009).

-Pisano E, Angelini C, Mazzei F, Stanyon R: Adaptive radiation in Antarctic notothenioid fish: studies of genomic change at chromosomal level. Ital J Zool 67:S115-S121 (2000).

Poletto AB, Ferreira IA, Martins C: The B chromosome of the cichlid fish Haplochromis obliquidens harbors 18S rRNA genes. BMC Genet 11:1 (2010a).

-Poletto AB, Ferreira IA, Cabral-de-Mello DC, Nakajima RT, Mazzuchelli J, et al: Chromosome differentiation patterns during cichlid fish evolution. BMC Genet 11:50 (2010b).

-Ráb P, Crossman EJ: Chromosomal NOR phenotypes in North American pikes and pickerels, genus Esox, with notes on the Umbridae (Euteleostei: Esocae). Canad J Zool 72:1951-1956 (1994).

-Ráb P, Rábová M, Reed KM, Phillips RB: Chromosomal characteristics of ribosomal DNA in the primitive semionotiform fish, longnose gar Lepisosteus osseus. Chromosome Res 7: 475-480 (1999).

Ráb P, Crossman EJ, Reed KM, Rábová M: Chromosomal characteristics of ribosomal DNA in two extant species of North American mudminnows Umbra pygmaea and U. limi (Euteleostei: Umbridae). Cytogenet Genome Res 98:194-198 (2002).

-Rábová M, Ráb P, Ozouf-Costaz C: Extensive polymorphism and chromosomal characteristics of ribosomal DNA in a loach fish, Cobitis vardarensis (Ostariophysi, Cobitidae) detected by different banding techniques and fluorescence in situ hybridization (FISH). Genetica 111:413-422 (2001).

Raskina O, Belyayev A, Nevo E: Quantum speciation in Aegilops: molecular cytogenetic evidence from rDNA cluster variability in natural populations. Proc Natl Acad Sci USA 101: 14818-14823 (2004).

Ravi V, Venkatesh B: Rapidly evolving fish genomes and teleost diversity. Curr Opin Genet Dev 18:544-550 (2008).

Reed KM: Tc1-like transposable elements from the genome of lake trout (Salvelinus namaycush). Mar Biotech 1:60-67 (1999).

Reed KM, Phillips RB: Molecular cytogenetic analysis of the double- $\mathrm{CMA}_{3}$ chromosome of lake trout, Salvelinus namaycush. Cytogenet Cell Genet 70:104-107 (1995).

Reed KM, Phillips RB: Polymorphism of the nucleolus organizer region (NOR) on the putative sex chromosomes of Arctic char (Salvelinus alpinus) is not sex related. Chromosome Res 5:221-227 (1997).

- Reed KM, Phillips RB: Structure and organization of the rDNA intergenic spacer in lake trout (Salvelinus namaycush). Chromosome Res 8: 5-16 (2000).

Reed KM, Hackett JD, Phillips RB: Comparative analysis of intra-individual and inter-species DNA sequence variation in salmonid ribosomal DNA cistrons. Gene 249:115-125 (2000).
Rosa KO, Ziemniczak K, de Barros AV, Nogaroto V, Almeida MC, et al: Numeric and structural chromosome polymorphism in Rineloricaria lima (Siluriformes: Loricariidae): fusion points carrying $5 \mathrm{~S}$ rDNA or telomere sequence vestiges. Rev Fish Biol Fisheries 22: 739-749 (2012).

Rossi AR, Gornung E: Cytogenetic analysis of three Italian populations of Coregonus lavaretus (Pisces, Salmoniformes) with chromosomal localization of major and minor ribosomal genes, and telomeric repeats. Hereditas 142:15-21 (2005).

Rossi AR, Gornung E, Crosetti D, De Innocentiis S, Sola L: Cytogenetic analysis of Oedalechilus labeo (Pisces: Mugilidae), with a report of NOR variability. Mar Biol 136:159-162 (2000).

Roussel P, Hernandez-Verdun D: Identification of Ag-NOR proteins, markers of proliferation related to ribosomal gene activity. Exp Cell Res 214:465-472 (1994).

Rubert M, da Rosa R, Jerep FC, Bertollo LAC, Giuliano-Caetano L: Cytogenetic characterization of four species of the genus Hypostomus Lacépède, 1803 (Siluriformes, Loricariidae) with comments on its chromosomal diversity. Comp Cytogenet 5:397-410 (2011).

- Salvadori S, Deiana AM, Coluccia E, Florida G, Rossi E, Zuffardi O: Colocalization of $(\mathrm{TTAGGG})_{\mathrm{n}}$ telomeric sequences and ribosomal genes in Atlantic eels. Chromosome Res 3:54-58 (1995).

Schubert I, Wobus U: In situ hybridization confirms jumping nucleolus organizing regions in Allium. Chromosoma 92:143-148 (1985).

Sczepanski TS, Noleto RB, Cestari MM, Artoni RF: A comparative study of two marine catfish (Siluriformes, Ariidae): cytogenetic tools for determining cytotaxonomy and karyotype evolution. Micron 41:193-197 (2010).

- Singh M, Kumar R, Nagpure NS, Kushwaha B, Gond I, Lakra WS: Chromosomal localization of $18 \mathrm{~S}$ and $5 \mathrm{~S}$ rDNA using FISH in the genus Tor (Pisces, Cyprinidae). Genetica 137:245252 (2009)

Sola L, Monaco PJ, Rasch EM: Cytogenetics of bisexual/unisexual species of Poecilia. I. Cbands, Ag-NOR polymorphisms, and sex chromosomes in three populations of Poecilia latipinna. Cytogenet Cell Genet 53:148-154 (1990).

Sola L, Cordisco C, Bressanello S, Cataudella S: Cytogenetic characterization of the North American white sturgeon Acipenser transmontanus (Pisces, Acipenseridae), in: Abstracts of VIII Cong. SEI, Oviedo, Spain, pp 64-65 (1994).

Sola L, Gornung E, Naoi H, Gunji R, Sato C, et al: FISH-mapping of $18 \mathrm{~S}$ ribosomal RNA genes and telomeric sequences in the Japanese bitterlings Rhodeus ocellatus kurumeus and Tanakia limbata (Pisces, Cyprinidae) reveals significant cytogenetic differences in morphologically similar karyotypes. Genetica 119:99-106 (2003).
Sola L, Gornung E, Mannarelli ME, Rossi AR: Chromosomal evolution in Mugilidae, Mugilomorpha: an overview, in Pisano E, OsoufCostaz C, Foresti F, Capoor AG (eds): Fish Cytogenetics, pp 165-194 (Science Publisher Inc, Enfield 2007).

-Souza L, Swarça AC, Dias AL: Analyses of the nucleolus organizer region in 5 species of the genus Pimelodus (Siluriformes, Pimelodidae) using $\mathrm{AgNO}_{3}, \mathrm{CMA}_{3}$ and FISH with the $18 \mathrm{~S}$ rDNA probe. Caryologia 57:145-151 (2004).

Symonová R, Flajšhans M, Gela D, Pelikánová S Rábová M, Ráb P: Tetraploidy in paddlefish, Polyodon spathula? - 34 years later. 19th International Colloquium on Animal Cytogenetics and Gene Mapping. Chromosome Res 18:754 (2010).

-Tagliavini J, Williot P, Congiu L, Chicca M, Lanfredi M, et al: Molecular cytogenetic analysis of the karyotype of the European Atlantic sturgeon, Acipenser sturio. Heredity 83:520525 (1999).

Takai A, Ojima Y: Some features on nucleolus organizer regions in fish chromosomes, in Uyeno T, Arai R, Taniuchi T, Matsuura K (eds): Indo-Pacific Fish Biology, pp 899-909 (Ichthyological Society of Japan, Tokyo 1986).

Vicari MR, Artoni RF, Moreira-Filho O, Bertollo LAC: Colocalization of repetitive DNAs and silencing of major rRNA genes. A case report of the fish Astyanax janeiroensis. Cytogenet Genome Res 122:67-72 (2008).

-Vitturi R, Libertini A, Campolmi M, Calderazzo F, Mazzola A: Conventional karyotype, nucleolar organizer regions and genome size in five Mediterranean species of Syngnathidae (Pisces, Syngnathiformes). J Fish Biol 52:677-687 (1998).

-Vitturi RR, Colomba MM, Vizzini S, Libertini A, Barbieri R, Mazzola AA: Chromosomal location polymorphism of major rDNA sites in two Mediterranean populations of the killifish Aphanius fasciatus (Pisces: Cyprinodontidae). Micron 36:243-246 (2005)

Wasko AP, Galetti PM Jr: Mapping 18S ribosomal genes in fish of the genus Brycon (Characidae) by fluorescence in situ hybridization (FISH). Genet Mol Biol 23:135-138 (2000).

-Whitehead CM, Winkfein RJ, Fritzler MJ, Rattner JB: ASE-1: a novel protein of the fibrillar centers of the nucleolus and nucleolus organizer region of mitotic chromosomes. Chromosoma 106:493-502 (1997).

Wright JE, Mais C, Prieto JL, McStay B: A role for upstream binding factor in organizing ribosomal gene chromatin. Biochem Soc Symp 73: 77-84 (2006).

Zhuo L, Reed KM, Phillips RB: Hypervariability of ribosomal DNA at multiple chromosomal sites in lake trout (Salvelinus namaycush). Genome 38:487-496 (1995).

Ziemniczak K, Barros AV, Rosa KO, Nogaroto V, Almeida MC, et al: Comparative cytogenetics of Loricariidae (Actinopterygii: Siluriformes): emphasis in Neoplecostominae and Hypoptopomatinae. Ital J Zool 79:492-501 (2012). 